\title{
Manajemen Sejarah Berbasis Komunitas: Pengembangan Kawasan Kauman sebagai Living Museum
}

\author{
Nur Aini Setiawati \\ Departemen Sejarah, Fakultas Ilmu Budaya, Universitas Gadjah Mada
}

Tim pengabdian kepada masyarakat:

Nur Aini Setiawati, Farabi Fakih, Anggraeni, D.S. Nugrahani, Popi Irawan, Daru Winarti, dan bersama mahasiswa yaitu: Baldika Badra Anggakara, Mubarok, Adhi Kurniawan, Herwida Putri Agista.

\begin{abstract}
Abstrak
Pengabdian masyarakat yang dikembangkan oleh Fakultas Ilmu Budaya ini adalah melakukan pendampingan terhadap Komunitas Kampung Kauman untuk menyiapkan Pengembangan Kawasan Kauman Yogyakarta sebapai Living Museum. Dalam hal ini kawasan Kauman akan dijadikan sebagai semacam kampung yang memiliki tradisi budaya yang berkelanjutan dari masa berdirinya Kasultanan Ngayogyokarto Hadiningrat sampai saat ini. Sesuai dengan konsep Living Museum, pengembangan yang akan dilakukan adalah dengan melengkapi tradisi budaya kawasan Kampung Kauman sesuai dengan wawancara dari sesepuh kampung tokoh-tokoh kampong dan generasi muda tentang sejarah terbentuknya Kampung Kauman. Wawancara yang diperoleh pada dasarnya merupakan intangible heritage, yang kemudian narasi itu diattachkan pada bentang lahan/lansekap kampung Kauman. Hasil yang diperoleh merupakan kolektif memori penduduk Kampung Kauman terhadap sejarah perkembangan Kampung Kauman. Penyusunan dan penentuan terhadap lokasi, gedung/bangunan, rumah narasi pembentukan sejarahnya,dan tradisi yang dilakukan secara rutin dalam satu tahun merupakan dasar awal bagi terselenggaranya historical living museum.
\end{abstract}

\begin{abstract}
One of the community services developed by the Faculty of Cultural Sciences provides an assistance to the community of Kauman village in preparation for Kauman village development as Yogyakarta living museum. In this case, Kauman area will serve as a kind of village that has a sustainable cultural tradition since the founding of Ngayogyokarto Hadiningrat Sultanate. In accordance with the concept of the living museum, many kinds of ideas will be implemented to regain the old cultural traditions that were taken from interviews with Kauman elders, community figures, and young people about the history of Kampung Kauman. The interviews are basically an intangible heritage which its narrative was attached to the landscape of Kauman village. The results obtained from the interviews is a collective memory of Kauman village society to the development history of Kauman village. The compilation and determination of the location, the building, the narrative house of historical formation, and the tradition that is carried out regularly in one year is the initial basis for the implementation of the historical living museum
\end{abstract}

Keywords: Kauman, Living Museum, Collective Memory 


\section{Pendahuluan}

Perkembangan industri warisan budaya (heritage industry) di Indonesia telah didorong oleh organisasi baik internasional, seperti UNESCO, maupun organisasi nasional dan lokal yang memiliki agenda dengan sudut pandang di luar wilayah tempat warisan budaya (heritage) itu berada. Pada saat yang bersamaan, di berbagai tempat di Indonesia telah muncul beragam paguyuban ataupun organisasi yang berbasis pada komunitas lokal. Dalam hal ini, komunitas lokal yang dimaksud ialah yang memiliki ketertarikan untuk mengembangkan potensi warisan budaya (heritage) yang berada di wilayahnya dengan sudut pandang pembangunan sistem lokal yang berkelanjutan.

Saat ini berkembang tren pariwisata warisan budaya (heritage tourism) dengan objek tempat-tempat bersejarah. Kegiatan pariwisata tersebut dikelola oleh komunitaskomunitas yang sebagian besar tidak mempunyai latar belakang keahlian baik di bidang industry pariwisata warisan budaya (heritage tourism industry) maupun ilmu-ilmu lain yang mendukung, seperti arkelogi, antropologi, sejarah, dan arsitektur. Bagaimanapun juga, komunitas-komunitas tersebut telah berhasil membentuk sebuah sistem yang cenderung sukses dalam menyelenggarakan beragam atraksi wisata, mulai dari kegiatan jalan-jalan menelusuri tempat-tempat bersejarah, yang sering kali diperkaya pula dengan diskusi atau ceramah dengan mengundang ahli. Kesuksesan tersebut dapat diraih dengan memanfaatkan peran media mutakhir berbasis internet.

Organisasi seperti Kota Toea Magelang di Magelang atau Aleut Community di Bandung, merupakan contoh kelompok-kelompok berbasis masyarakat lokal yang sukses menawarkan narasi baru tentang sejarah kota masing-masing. Selain mampu menggaet banyak peminat, kesusksesan tersebut juga mendapat apresiasi para sejarawan professional. Diakui bahwa potensi yang mereka miliki sangat menakjubkan, sehingga mereka dapat menjadi ujung tombak dalam memasyarakatkan dan mengangkat sejarah di daerahnya. Tidak hanya itu, karena mereka memerlukan keberadaan tempat-tempat bersejarah termasuk sarana dan prasarananya, maka kelompok seperti itu juga dapat menjadi ujung tombak dalam pelestarian warisan budaya. Dengan demikian masyarakat lokal tersebut dapat mengambil peran aktif di bidang pelestarian sekaligus dapat membuat berbagai hal yang dilestarikan tersebut dapat diakses oleh publik dalam koridor yang tidak bertentangan dengan prinsip pelestarian.

Berdasarkan uraian di atas, maka kegiatan pengabdian yang dikembangkan oleh Fakultas Ilmu Budaya ini adalah melakukan pendampingan terhadap Komunitas Kampung Kauman untuk menyiapkan Pengembangan Kawasan Kauman Yogyakarta sebagai Living Museum.

Berdasarkan uraian di atas, maka kegiatan Pengabdian Kepada Masyarakat (PKM) yang akan dikembangkan oleh Fakultas Ilmu Budaya - Universitas Gadjah Mada (FIBUGM) ialah melakukan Pendampingan terhadap Komunitas Kampung Kauman untuk menyiapkan Pengembangan Kawasan Kauman Yogyakarta sebagai Living Museum

\section{Permasalaban}

Berdasarkan latar belakang uraian diatas dapat dirumuskan permasalahan sebagai berikut:

- Bagaimana manajemen pengembangan wisata kampung Kauman sebagai living museum? 
- Potensi wisata apa saja yang dimiliki kampung Kauman untuk mengembangkan daerah wisata?

\section{Tujuan}

Dua kegiatan utama untuk memfasilitasi pembentukan living museum ialah aspek penggalian dan penulisan sejarah yang bersifat kritis. Kedua ialah aspek manajemen museum, khususnya strategi manajemen informasi dan konsumsi produk living museum yang berkelanjutan. Melalui gambaran kegiatan tersebut di atas, maka tujuan yang dicanangkan ialah:

- Tujuan Jangka Pendek ialah menyiapkan Komunitas Kampung Kauman untuk membuat blue print tentang living history Kawasan Kauman Yogyakarta.

- Tujuan Jangka Menengah ialah melakukan pendampingan terhadap Komunitas Kampung Kauman agar blue print tentang living history Museum Kawasan Kauman Yogyakarta yang dibuat pada 2017 dapat diimplementasikan. Oleh karena itu, tujuan jangka menegahnya ialah menguji cobakan blue print yang dihasilkan.

\section{Sasaran}

Memperdayakan potensi sejarah serta mengembangkan potensi wisata di Kampung Kauman Yogyakarta, sehingga akan didapatkan informasi tentang sejarah dan juga mempromosikan kampung wisata Kauman yang penuh dengan sejarahnya melalui media sosial.

\section{Metode Pelaksanaan}

PKM ini akan dilaksanakan dengan metode FGD untuk memetakan potensi yang dimiliki Komunitas Kampung Kauman dalam merancang living museum. Selain FGD, metode lain yang digunakan ialah metode pendampingan oleh Tim PKM yang akan bertindak sebagai fasilitator. Metode pendampingan diterapkan pada saat Komunitas Kampung Kauman membuat pangkalan data terkait dengan Manajemen Sejarah terkait Kauman-Kraton-Titik Nol Yogyakarta.

Adapun bentuk permasalahan yang dihadapi Kampung Kauman secara umum adalah kurangnya kemampuan ditingkat keterampilan manajerial yaitu belum dimilikinya pengetahuan para pengelola wisata Kampung Kauman tentang cara pengembangan potensi wisata belum dilakukan, hal ini perlu diperhatikan lagi mengingat potensi wisata alam yang dimiliki kampung Kauman bisa di kembangkan untuk dijadikan produk wisata yang lebih menarik dan terorganisir. Dari persoalan yang disampaikan oleh Ketua Saka wisata tentang mengelola kampung wisata, maka perlu dilakukan pengabdian masyarakat terhadap pendampingan pembuatan leaflet dan website, serta mengelola jalannya pariwisata di Kampung Kauman.

\section{Pembahasan}

Pelaksanaan Pengabdian Kegiatan Pada Masyarakat telah mencapai beberapa kegiatan yang diselenggarakan yaitu:

1. Memberikan pemahaman tentang pentingnya sejarah Kampung Kauman dan 
mendampingi masyarakat Kauman yang tergabung dalam "Saka Wisata” untuk menuliskan sejarahnya.

2. Memberikan pendampingan dengan memasukan konten-konten paket wisata dan sejarah Kauman pada website.

3. Evaluasi program tentang manfaat dan fungsi penulisan sejarah Kampung Kauman dan potensi wisatanya.

Potensi wisata kami fokuskan pada kampung Kauman yang memiliki potensi peninggalan sejarah, kampung yang melahirkan persyarikatan Muhammadiyah, kampung perjuangan masa Revolusi Fisik, kampung Batik dan kampung kuliner.

\section{Sejarab Kauman}

Jika berbicara mengenai Yogyakarta maka yang terlintas di pikiran kita adalah Keraton. Keraton Yogyakarta memang menjadi pusat pemerintahan sekaligus pusat kebudayaan pada masanya. Kota ini memiliki sejarah yang cukup panjang, Yogyakarta pernah menjadi pusat Kerajaan Mataram Islam hingga menjadi Ibukota sementara pada masa Revolusi. Perkembangan Islam di Yogyakarta tidak bisa lepas dari kampung Kauman yang merupakan bagian dari struktur birokrasi keraton Yogyakarta. Kauman merupakan sebuah kampung yang terletak disekitar Masjid Agung, jika dilihat dari struktur tata ruang kota konsep perkampungan menjadi sangat penting sebagai suatu tempat tinggal.

Kauman adalah nama sebuah kampung yang berada dalam wilayah Kraton Yogyakarta yang terletak di kelurahan Ngupasan, kecamatan Gondomanan, kotamadya Yogyakarta. Letak Kampung Kauman berada di barat Alun-alun Utara Kraton Yogyakarta dengan luas $192.000 \mathrm{~m}^{2}$, sebelah barat dibatasi Jalan Nyai Ahmad Dahlan, sebelah selatan Jalan Kauman, sebelah Utara dibatasi Jalan Nyai Ahmad Dahlan.

Kampung Kauman yang berada di sekitar Masjid Agung ini memiliki sejarah yang cukup menarik. Sampai sekarang bangunan di Kampung Kauman masih terjaga keasliannya, bangunan bersejarah seperti langgar masih berdiri kokoh. Rumah-rumah di Kauman memiliki ciri khas yang unik, terdapat pintu dan jendela yang besar yang merupakan perpaduan antara Jawa dan ornamen Eropa. Jika kita berjalan mengelilingi kampung ini kita akan menemui sebuah monumen "Syuhada Fisabilillah" yang dibangun untuk mengenang jasa para warga Kauman yang ikut bertempur dalam memperjuangkan kemerdekaan. Kampung Kauman awalnya tempat yang digunakan oleh pengulu atau pengurus keagamaan yang ditugaskan Keraton untuk mengelola Masjid Agung. Kampung ini juga sebagai basis munculnya organisasi Islam yaitu Muhammadiyah, selain juga menjadi kampung batik dan kuliner. Kampung Kauman sekarang menjadi salah satu destinasi wisata yang menarik untuk dikunjungi.

Berdirinya Kampung Kauman tidak terlepas dari Masjid Agung, Sultan Hamengku Buwono I membangun Masjid Agung pada tahun 1773 yang terletak di sebelah barat alun-alun. Pembangunan masjid ini bertujuan sebagai tempat mengadakan kegiatan keagamaan yang diadakan oleh Keraton. Untuk mengelola masjid tersebut Sultan Hamengku Buwono I memberikan sebidang tanah disekitar masjid kepada Abdi Dalem dan ulama. Dalam mengelola Masjid Agung, dibentuklah sebuah lembaga yang bernama Kapenguluan yang bertugas mengelola masjid tersebut, sedangkan kantor dari kapenguluan tersebut dinamakan Kapengulon (Darban, 2000: hlm. 10). Pengulu 
di sini memiliki tugas yang berkaitan dengan bidang keagamaan seperti mengurusi pernikahan, perceraian, menjadi juru kunci makam, dan lain-lainnya. Pemukiman di sekitar masjid inilah yang kemudian dikenal dengan kampung Kauman. Kauman berasal dari kata qaum yang berarti pejabat agama. Di sinilah tempat tinggal para kaum ulama, santri dan pengulu.

Kampung ini menjadi pusat perkembangan agama Islam dan juga sebagai tempat lahirnya Muhamadiyah. Kauman merupakan kawasan tempat tinggal abdi dalem yang mengurusi agama atau disebut wilayah Pamethakan dan juga lahirnya organisasi Islam Muhammadiyah pada tahun 1912. Munculnya Muhamadiyah tidak terlepas dari peran seorang tokoh yang bernama K.H Ahmad Dahlan yang juga merupakan seorang ketib/pengulu di Masjid Agung. Ahmad Dahlan mulai mengubah kebudayaan Islam tradisional yang ada dalam masyarakat menjadi Islam yang lebih modernis. Pembaruan ini dilakukan karena mayoritas masyarakat di Indonesia mengalami keterbelakangan dan sistem pengajaran Islam yang sudah tidak relevan lagi (Maarif, 1986, hlm. 66). Tujuan dilakukan gerakan pembaharuan ini tidak lain untuk menjaga kemurnian Aqidah Islamiyah dan Ukhuwah Islamiyah. Dengan berdirinya Muhammadiyah, Kauman menjadi perkampungan yang semakin dikenal karena banyak menghasilkan alim ulama. Pada masa kemerdekaan Kauman juga menjadi basis pertahanan para gerilyawan. Para pemuda kauman yang tergabung dalam Laskar Hizbullah Fisabilillah juga ikut bergerilya melawan penjajahan, yang berpusat di pelataran Masjid Agung. Di pelataran masjid inilah para pemuda menghimpun kekuatan dan juga menyusun strategi bersama para gerilyawan (Wawancara dengan Bapak Gatot pada Jumat, 10 November 2017, pukul 16: 12).

Hubungan masyarakat di Kauman semakin berkembang karena didasari oleh kesamaan agama, kesamaan jabatan sebagai abdi dalem dan juga pertalian darah yang kuat, hal ini membuat kampung Kauman memiliki karakteristik yang unik. Terbentuknya masyarakat Kauman sangat dipengaruhi oleh Masjid Agung, itu artinya masjid sebagai tempat peribadatan Islam mempengaruhi masyarakat sekitarnya. Perilaku masyarakat Kauman dalam kehidupan keseharian mencerminkan keislaman, yang dapat dilihat melalui rutinitas menjalankan sholat lima waktu dan mengadakan pengajian. Sampai sekarang pun kegiatan pengajian yang dilaksanakan di Masjid Agung masih berjalan. Dalam sepekan terdapat 5 sampai 6 acara pengajian (Wawancara dengan Bapak Gatot pada Jumat, 10 November 2017, pukul 16: 17). Hal ini menunjukan bahwa konsistensi masyarakat Kauman masih terjaga hingga sekarang. Tidak hanya pengajian, kegiatan yang berhubung dengan keagamaan masih terjaga seperti acara grebeg maulid dan syawalan.

\section{Masyarakat Kauman}

Secara umum masyarakat Kauman terbentuk karena faktor pertalian darah, perkawinan antar warga Kauman menjalin suatu pertalian darah yang kuat. Hal semacam ini dinamakan endogami yaitu melakukan perkawinan antar warga yang berada pada satu kampung yang sama (Darban, 2000, hlm. 18).

Awalnya mata pencaharian masyarakat Kauman bersifat homogen hanya mengandalkan pekerjaan sebagai abdi dalem. Akan tetapi, pada tahun 1930-an masyarakat Kauman mulai mencari inisiatif untuk mendapatkan hasil tambahan yaitu 
dengan cara menjadi pengrajin dan pedagang batik. Dari sini ekonomi masyarakat Kauman mengalami kenaikan, budaya pengrajin dan membatik menjadi identitas baru bagi masyarakat Kauman. Kesatuan sosial dan berdirinya Muhammadiyah menjadi penentu perubahan dalam bidang ekonomi. Masyarakat Kauman yang berkembang dari pengrajin batik menjadi pengusaha batik, para pengusaha batik ini disebut dengan kaum saudagaran karena kegiatan ekonomi mereka pada sektor perdagangan (Surjomihardjo, 2000, hlm 37). Para pengusaha batik ini menjadi suatu komunitas yang bernama Batik Handel. Akan tetapi, eksistensi pengrajin dan pengusaha batik Kauman mulai meredup pada tahun 1980-an.

Pondok pesantren merupakan tempat pendidikan masyarakat Kauman, sejak kecil hingga dewasa masyarakat Kauman terdidik dengan nuansa keislaman. Pondok pesantren biasanya berada pada masjid dan langgar di sekitar kampung Kauman. Dalam masyarakat pesantren, masjid menjadi salah satu elemen yang penting, masjid digunakan sebagai tempat diadakanya kegitan pembelajaran kaum santri dan kegiatan kelembagaan. Masuknya sistem pendidikan gaya barat semakin menggeser pondok pesantren hingga pada akhirnya pada tahun 1913 warga Kauman mendirikan sekolah kyai sebagai sekolah umum. Sekolah kyai kemudian berubah nama menjadi Volkschool Muhammadiyah Kauman Yogyakarta setara dengan pendidikan Volkschool atau sekolah desa tiga tahun (Darban, 2000, hlm. 21). Hadirnya sekolah umum tersebut semakin membuka pengetahuan baru bagi masyarakat Kauman.

Ciri yang khas dari masyarakat Kauman masih dapat kita jumpai sampai saat ini, shalat berjamaah dan pengajian rutin masih berjalan hingga sekarang. Akan tetapi, seiring perkembangan zaman ada perubahan pola kehidupan dalam masyarakat Kauman. Masyarakat yang dulu bekerja sebagai abdi dalem pamethakan kini mata pencaharian masyarakat Kauman lebih bervariatif dan tidak terikat oleh birokrasi kerajaan.
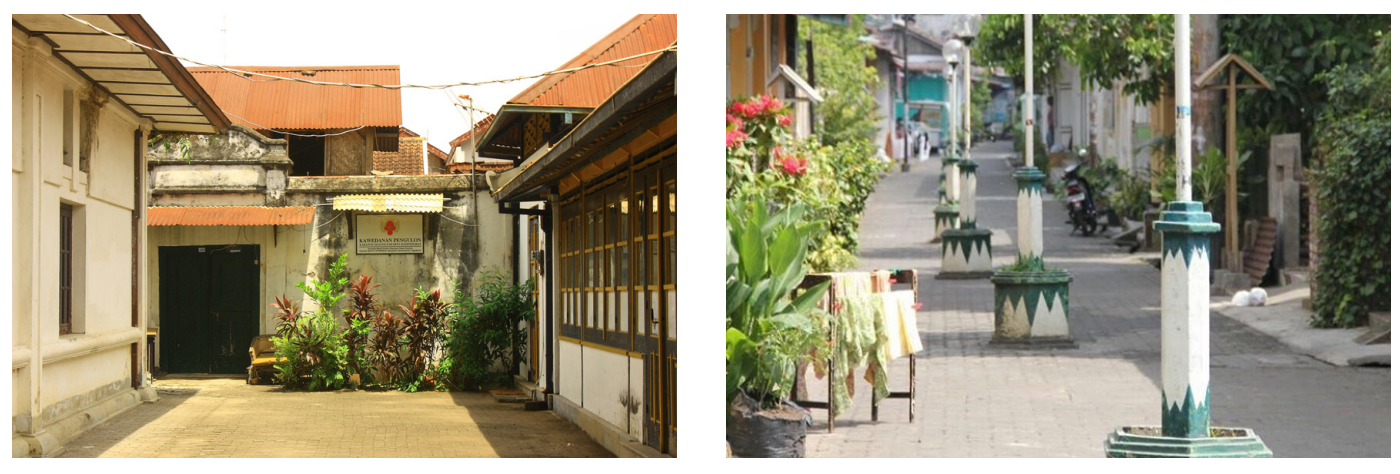

Foto 1 dan 2. Kampung Kauman

\section{Masjid Agung Kauman dan Langgar}

Berdirinya Kota Yogyakarta memang tidak bisa dilepaskan dengan peranan Keraton Kasultanan Yogyakarta yang mendampinginya. Kota yang memiliki sejarah panjang meninggalkan banyak sekali bangunan bersejarah. Jika mengunjungi Keraton Yogyakarta tak lengkap rasanya jika tidak mengunjungi Masjid Agung Kauman. Di Indonesia, masjid sudah muncul sejak keberadaan kerajaan bercorak Islam di Jawa. Keberadaan 
masjid ini menunjukan pengaruh Islam yang mulai masuk ke Indonesia. Masjid tersebut memiliki karakter dan ciri khas masing-masing di setiap wilayah Indonesia.

Salah satu masjid yang memiliki sejarah di Yogyakarta adalah Masjid Agung Kauman yang terletak disebelah barat alun-alun utara Keraton Yogyakarta. Terletak di kelurahan Ngupasan, kecamatan Gondomanan, Daerah Istimewa Yogyakarta. Masjid Agung Kauman menjadi salah satu destinasi wisata religi yang menarik untuk dikunjungi.

Masjid ini didirikan oleh Sultan Hamengku Buwono I pada tahun 1773 dengan Kyai Faqih Diponingrat, sedangkan arsitektur Masjid Kauman ditukangi oleh Kyai Wirokromo (Darban, 2000, hlm. 9). Jika dilihat dari tata letaknya masjid ini tepat berada disebelah barat dari alun-alun utara Yogyakarta. Bangunan induk masjid ini berbentuk limasan dan memiliki atap bertumpang tiga yang diatasnya terdapat mustaka. Di sebelah utara dan selatan masjid terdapat bangunan yang bernama Pagongan, bangunan ini berfungsi sebagai tempat gamelan pusaka yang digunakan pada saat acara sekaten. Masjid Kauman sendiri dibangun untuk tempat beribadah sultan sekaligus menjadi salah satu simbol bagi kerajaan islam.

Guna menampung jama’ah lebih banyak Masjid Kauman melakukan penambahan serambi pada tahun 1775 yang dinamakan al makhamah-al kabiroh (Darban, 2000, hlm. 9). Serambi ini juga digunakan sebagai tempat pertemuan dan musyawarah para ulama. Serambi masjid terdiri dari dua lantai, bagian atas terdiri dari 24 tiang penyangga dan bagian bawah terdapat 32 tiang penyangga. Bangunan masjid ini mempunyai luas $2.578 \mathrm{~m}^{2}$ yang terdiri dari ruang shalat utama dan serambi masjid (Atmojo, 1998/1999, hlm. 175). Adapun yang sisanya digunakan untuk ruang pawestren, pabongan, pawudon, perpustakaan dll. Secara keseluruhan luas kompleks masjid ini mencapai $16.000 \mathrm{~m}^{3}$. Bangunan masjid ini memiliki gaya arsitek tradisional jawa yang penuh dengan filosofi.

Untuk mengelola masjid maka dibentuklah sebuah lembaga yang bernama Kepenguluan yang berfungsi sebagai penasihat sekaligus sebagai sebuah birokrasi kerajaan yang mengelola bidang keagamaan. Orang-orang yang mengurus masjid ini adalah para ulama atau yang disebut dengan abdi dalem pamethakan, karena menggunakan pakaian yang serba putih, yang ditugaskan untuk mengatur birokrasi masjid (Moedjanto, 1994, hlm. 110).

Kauman sebagai kampung santri menghasilkan banyak alim ulama yang berpengaruh dalam masyarakat. Selain masjid juga terdapat langgar/mushola yang digunakan untuk kegiatan keagamaan. Langgar ini digunakan sebagai pesantren kecil oleh masyarakat sekitar. Pelajaran yang diajarkan di sini mengenai tasawuf dan ilmu fiqih. Di Kauman sendiri terdapat beberapa langgar di antaranya (Wawancara dengan Bapak Gatot pada Jumat, 10 November 2017, pukul 16: 29):

Langgar Ar Rasyad atau langgar Kyai Nur karena dipimpin oleh Kyai M. Nur setelah sepeninggal Kyai Nur langgar ini dikelola oleh putrinya yaitu Nyai Jainab jama’ah di sini bernama jama'ah Nuriyah.

- Langgar Duwur yang dipimpin oleh K.H Muhsen.

- Langgar Faqih yang dipimpin oleh Kyai Faqih.

- Langgar Kidul atau langgar K.H Ahmad Dahlan, langgar ini digunakan oleh Ahmad Dahlan sebagai tempat pembaruan ajaran Islam sebelum lahirnya Muhammadiyah.

- Musholla Aisyah yang digunakan khusus untuk jama’ah putri. 
Langgar-langar di atas sampai sekarang masih digunakan untuk tempat beribadah dan juga digunakan untuk kegiatan keagamaan seperti pengajian. Dari keseluruhan langgar tersebut langgar yang memiliki makna historis adalah langgar kidul atau langgar Ahmad Dahlan karena lahirnya organisasi Islam pertama berawal dari langgar tersebut.

Masjid Agung Kauman tidak hanya berfokus pada kegiatan keagamaan saja tetapi juga pada bidang pendidikan. Pendidikan yang dimaksud di sini ialah pendidikan pondok pesantren. Ketika membicarakan pesantren maka selalu dikaitkan dengan masjid dan santri, karena kedua unsur ini saling mengikat dan berkaitan satu sama lain. Dalam pesantren sistem pengajaranya menggunakan sistem sorogan, bandongan, dan wetonan (Manshur, 1998, hlm. 46). Sorogan dalam bahasa Jawa memiliki arti menyodorkan, dalam hal ini santri memberikan atau menyodorkan materi yang ingin dipelajari sehingga mendapat bimbingan secara khusus oleh sang Kyai. Dengan metode ini santri diwajibkan menguasai cara pembacaan dan terjemahan. Bandongan, metode ini dilakukan oleh santri secara bersama-sama atau bisa dikatakan dengan sistem ceramah. Wetonan, dalam metode ini Kyai yang memberikan pembelajaran kepada santri atau biasa disebut dengan majelis ta'lim. Pesantren sebagai pusat pendidikan Islam tidak hanya mengajarkan mengenai pengetahuan dasar islam tetapi juga mempelajari tata cara berpikir orang Islam.

Masjid merupakan sebuah unsur pesantren yang memiliki fungsi sebagai pusat pendidikan keagamaan dan kegiatan kemasyarakatan. Sampai sekarang kegiatan yang berbau keagamaan masih dilakukan di Masjid Agung seperti sekaten. Sekaten atau grebeg merupakan acara peringatan hari-hari besar dalam Islam (Jandra, 1989-1990, hlm. 220225). Terdapat tiga macam grebeg, pertama adalah grebeg syawal yang diadakan pada hari raya Idul Fitri, kedua grebeg besar yang diadakan pada hari raya Idul Adha, dan yang terakhir grebeg mulud yang diadakan untuk memperingati maulid nabi Muhammad SAW. Dalam acara grebeg terdapat dua gunungan, yang pertama gunungan jaler dan yang kedua gunungan estri. Gunungan ini berisi hasil pertanian dan jajanan tradisional yang mereprentasikan dari kemakmuran. Gunungan ini dibawa oleh abdi dalem mulai dari Kemandungan, alun-alun utara dan berakhir di halaman Masjid Agung. Acara keagamaan lain yang dilakukan di masjid yaitu Yasa Peksi Burak yang diadakan untuk memperingati Isra Miraj.

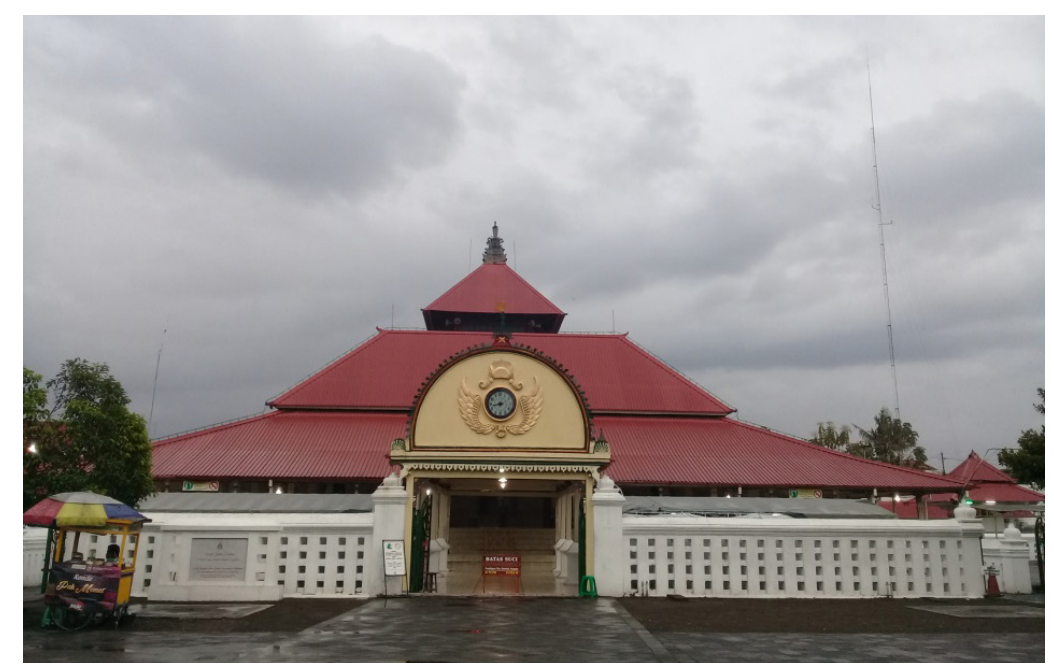

Foto 3. Masjid

Agung Kauman 


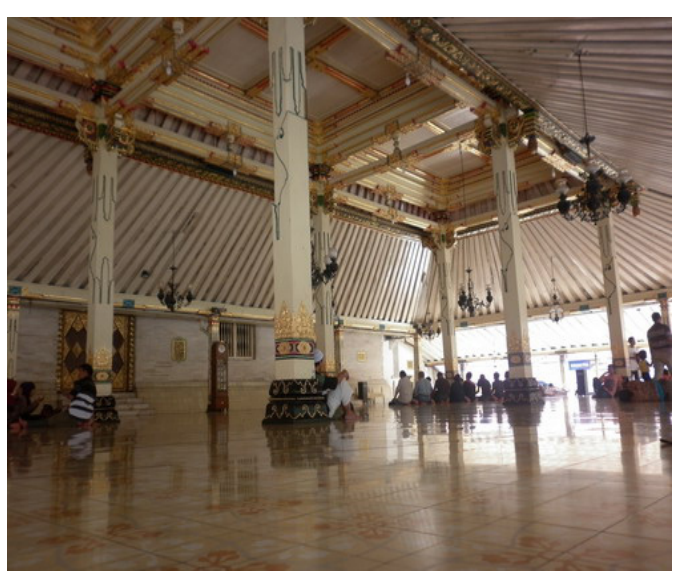

Foto 4. Serambi Masjid

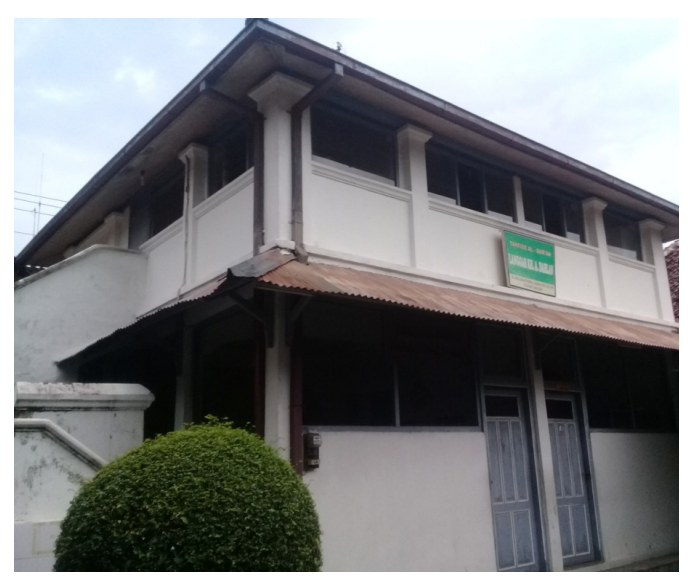

Foto 5. Langgar Kidul

(K.H Ahmad Dahlan)

\section{Mubammadiyab}

Muhammadiyah merupakan gerakan pembaruan Islam di Indonesia yang lahir atas dorongan kondisi-kondisi yang mengitari dunia Islam Indonesia pada awal abad ke20, antara lain kondisi sosial-politik, kultural, dan keagamaan (Sairin, 1995, hlm. 23). Diketahui bahwa Muhammadiyah didirikan oleh K.H. Ahmad Dahlan di Yogyakarta pada 18 November 1912. Menurut Syafii Maarif, faktor-faktor intern yang mendorong K.H. Ahmad Dahlan mendirikan Muhammadiyah yaitu keterbelakangan serta kebodohan umat Islam di Indonesia terhadap kehidupan, kemiskinan yang diderita oleh umat Islam di Indonesia, dan keadaan pendidikan Islam yang masih kuno. Sedangkan faktor-faktor ekstern, meliputi adanya kolonialisme Belanda di Indonesia, kegiatan serta kemajuan yang dicapai oleh golongan Kristen dan Katholik, sikap kaum intelektual yang memandang Islam sebagai agama yang ketinggalan zaman, dan kristenisasi pemerintah Belanda demi kepentingan kolonialnya. Jika disimpulkan secara ringkas, bahwa faktorfaktor yang mendorong terbentuknya Muhammadiyah dikarenakan kondisi Islam di Jawa, pengaruh gerakan modernis Islam di Timur Tengah, dan adanya politik Islam di pemerintahan Belanda (Sairin, 1995, hlm. 24-25). Selain itu, menurut Harun Nasution bahwa motivasi lain muncul dari ide-ide pemikiran Muhammad Abduh dan Muhammad Rasyid Ridha di Majalah Al-Manar.

Berawal dari K.H. Ahmad Dahlan membuka Madrasah Ibtida'iyah Diniyah Islamiyah pada 1 Desember 1911. Kegiatan-kegiatan di dalam Madrasah tersebut meliputi kegiatan belajar mengajar serta kegiatan amar ma'ruf nahi mungkar. Madrasah ini bertempat di ruang tamu rumah K.H. Ahmad Dahlan yang berisikan tiga meja dan tiga dingklik. Awalnya hanya berisikan sembilan murid, namun di tahun berikutnya bertambah menjadi dua puluh murid. Kebanyakan murid-murid tersebut berasal dari kalangan santri Kauman. Mereka masih tergolong asing dalam melakukan sistem bersekolah (Darban dkk., 1994, hlm. 26-27). Boedi Oetomo yang merupakan teman dekat K.H. Ahmad Dahlan, mengusulkan ide kepada K.H. Ahmad Dahlan untuk dibentuknya suatu organisasi terpadu dalam melestarikan kegiatan tersebut. Atas usulan tersebut, K.H. Ahmad Dahlan mulai memikirkan bahwa gerakan dakwah, pendidikan, dan gerakan kemasyarakatan memang harus dibutuhkan sebagai wadah organisasi 
yang nantinya sebagai tempat pembinaan umat muslim (Zahid dan Husein Al-Aydrus, 2013, hlm. 93). K.H. Ahmad Dahlan akhirnya memutuskan untuk menimba ilmu dari staf pengurus Jamiat Kheir, Sayyid Abdullah Al-Athas yang sudah lebih dahulu mengenal gagasan pembaharuan dan akses terhadap gagasan pencerahan Islam di Timur Tengah. Organisasi Jamiat Kheir inilah yang menginspirasi K.H. Ahmad Dahlan untuk mendirikan organisasi Islam yang modern.

Kemudian K.H. Ahmad Dahlan mengajak para santrinya untuk mendirikan organisasi yang dibantu oleh Boedi Oetomo dalam bidang teknisnya. Maka dipilihlah pada 18 November 1912 bertepatan dengan 8 Dzulhijah $1330 \mathrm{H}$ yang bernama Muhammadiyah atau "Jalan Muhammad". Lalu organisasi ini disahkan dengan mengirimkan Statuten Muhammadiyah yang pertama dan disahkan oleh Gubernur Jendral Belanda dalam Surat Ketetapan Pemerintah nomor 81 pada 22 Agustus 1914 (Zahid dan Husein Al-Aydrus, 2013, hlm. 93). Muhammadiyah didirikan tidak berfokus penuh pada perihal politik, melainkan lebih memfokuskan pada hal sosial dan pendidikan masyarakat. Menurut penuturan cucu K.H. Ahmad Dahlan yaitu Ibu Chairiah, bahwa,

"Ketika bakda subuh terdengar kentongan dari langgar Kauman Kidul, sehingga warga Kauman telah mengetahui bahwa Kyai Haji Raden Ngabehi Ahmad Dahlan akan melelang aneka isi rumahnya. Kemudian beberapa juragan batik dan warga lainnya bergegas mendatanginya untuk membeli barang-barang tersebut. Kemudian dana yang terkumpul digunakan untuk pembangunan sekolah dan perjuangan Islam".

Dalam perjalanannya, Muhammadiyah mencurahkan seluruh kegiatan sebelumnya serta meningkatkan dakwah-dakwah yang diharapkan dapat melawan agama Kristen dan takhayul-takhayul lokal. Untuk mengembangkan segala program-programnya, pada tahun 1917 dibentuklah sub Muhammadiyah seksi perempuan yang bernama "Aisyiyah" atau nama istri Nabi Muhammad yang dianggap memiliki peranan penting dalam modernisasi kehidupan perempuan (Ricklefs, 2008, hlm. 368). Berikut para pengurus Muhammadiyah yang pertama kali (Darban dkk., 1994, hlm.29):

$\begin{array}{ll}\text { Ketua } & \text { : Kyai Haji Ahmad Dahlan } \\ \text { Sekretaris } & \text { : H. Abdul Siraj } \\ \text { Anggota } & \text { : H. Ahmad } \\ & \text { H. Abdul Rahman } \\ & \text { R.H. Syarkawi } \\ & \text { H. Muhammad } \\ & \text { R. H. Jaelani } \\ & \text { H. Akis } \\ & \text { H. Muhammad Fakih }\end{array}$

Jika dilihat proses perkembangannya, awal perjalanan Muhammadiyah berkembang secara lamban. Organisasi ini ditentang dan diabaikan oleh para peejabat, guru-guru Islam gaya konvensional, komunitas saleh yang menentang ide-ide Islam modernis, serta birokrat-birokrat keagamaan yang lebih dahulu diakui oleh pemerintah. Meskipun

1 Narasi Ibu Chairiah, cucu K.H.R.Ng. Ahmad Dahlan di dalam VCD: Ahmad Dahlan, Seorang Bapak, Guru, dan Imam, diproduksi oleh Yayasan K.H. Ahmad Dahlan, 2010 yang tercantum pada buku karya Ahmad Sarwono bin Zahid dan Shofrotum binti Husein Al-Aydrus (2013, hlm. 94). 
begitu, pada tahun 1925 Muhammadiyah telah mendirikan 55 sekolah dengan 4.000 murid, sebuah panti asuhan, sebuah rumah miskin, serta dua balai pengobatan yang tersebar di Yogyakarta dan Surabaya (Ricklefs, 2008, hlm. 369). Perkembangan dan perjalanan karir Muhammadiyah ini tidak terlepas dari perhatian Sri Sultan Hamengku Buwono VIII yang memberikan "wejangan” kepada K.H. Ahmad Dahlan.

"Aja nganti Muhammadiyah ngucemake kawibawan Masjid Gedhe Kauman. Aku ora pengin Muhammadiyah nggawe congkrahe masyarakat bab keyakinan agama".

Maksud “wejangan” ini bahwa Sri Sultan Hamengku Buwono VIII tidak menginginkan organisasi Muhammadiyah ini nantinya dapat merendahkan syiar di Masjid Gedhe Kauman. Selain itu, organisasi ini diharapkan tidak menimbulkan perpecahan di kalangan umat muslim sendiri.

Pengaruh Muhammadiyah terhadap organisasi-organisasi perjuangan lainnya bermacam-macam responnya. Bagi penjajah Belanda, mereka mendirikan lembaga pendidikan semacam HIS, MULO, dan AMS ialah untuk menarik simpati kalangan pribumi untuk tidak bersekolah di lembaga pendidikan buatan K.H. Ahmad Dahlan. Walaupun begitu, para pengikut Muhammadiyah ini mayoritas merupakan lulusan dari HIS, MULO, dan AMS yang berkarakter tidak terlalu sekuler dan tidak proBelanda. Sehingga partisipasi mereka tidak terlalu berapi-api dalam memperjuangkan kemerdekaan, sebagaimana berbeda dari semangat gerakan Syarikat Islam yang benarbenar non kooperasi terhadap Belanda.

Pada dasarnya, Muhammadiyah memiliki pokok-pokok pikiran usaha yang dilaksanakan oleh K.H. Ahmad Dahlan, antara lain penyebaran agama Islam melalui sistem sekolah, penyebaran agama Islam melalui pengajian kelompok, penyebaran agama Islam melalui pembinaan masjid, dan penyebaran agama Islam melalui publikasi. Untuk mengimplementasikan pokok pikiran tersebut, kemudian Muhammadiyah mendirikan bagian-bagiannya seperti bagian Tabligh, bagian Taman Pusaka, bagian Penolong Kesengsaraan Umum, bagian Sekolahan, serta bagian kepanduan Hizbhoel Wathon. Dari pokok-pokok pikiran tersebut, Muhammadiyah mangaktualisasikan gerakannya dengan menumbuh kembangkan kondisi sosio-kultural di masyarakat lingkungannya (Darban dkk., 1994, hlm. 77-78).

\section{Revolusi Fisik}

Di Yogyakarta, berita proklamasi yang sampai di kantor berita "Domei" segera disebarluaskan secara diam-diam melalui para wartawan ke tokoh-tokoh masyarakat dan pemuda. Tersebarnya berita tersebut bertepatan pada hari Jumat pukul 12.00 siang hari, sehingga penyebarannya berhasil didengar oleh umat Islam yang telah selesai menjalankan shalat Jumat di Masjid Besar Kauman maupun Masjid Pakualaman. Hal tersebut dilakukan pula oleh Ki Hajar Dewantara yang mengajak para murid-muridnya untuk bersepeda mengililingi kota dan menyebarkan berita proklamasi ke seluruh kampung dan desa.

Mendengar kabar tersebut, pimpinan militer Jepang di Yogyakarta memerintahkan Tentara Serikat untuk menutup pemancar Hoso Kyoku. Hal tersebut menyebabkan masyarakat setempat buta berita dan tidak mengetahui apa yang harus mereka lakukan setelah adanya proklamasi kemerdekaan. Namun kegelisahan masyarakat tersebut 
dapat ditepis dengan munculnya surat kabar "Sinar Matahari” yang menjelaskan bahwa Indonesia telah benar-benar memproklamasikan kemerdekaan. Untuk merespon hal tersebut, Sri Sultan Hamengku Buwono IX memanggil Sri Paduka Alam VIII dan KRT Honggowongso untuk membicarakan bagaimana sikap yang harus dijalankan ke depannya. Akhirnya pada 19 Agustus 1945, Sri Sultan mengundang kelompok-kelompok pemuda yang terdiri dari golongan agama, nasionalis, kepanduan, dan keturunan Tionghoa ke Bangsal Kepatihan untuk merundingkan hal tersebut.

Hasil dari perundingan tersebut menyatakan bahwa Sri Sultan beserta rakyatrakyatnya di Yogyakarta merupakan bagian dari Republik Indonesia dan siap mengorbankan jiwa dan raga dalam mempertahankan kemerderkaan. Pada 21 September 1945, para pemuda nasionalis mengibarkan bendera merah putih di Gedung Cokan Kantai yang diawali dengan diturunkannya bendera Hinomaru. Tidak menghiraukan penjagaan yang ketat, pemuda-pemudi yang terdiri dari Kapten Polisi Slamet, Siti Ngaisyah, Sultan Ilyas, dan Supardi berhasil menerobos penjagaan para serdadu Jepang dengan bersenjatakan bambu runcing, golok, tombak, dan pedang.

Selain respon yang muncul dari kalangan pemuda nasionalis, para ulama-ulama di Yogyakarta turut merespon positif atas "wejangan-wejangan” yang disampaikan oleh Sri Sultan dalam perundingan tersebut. Hal tersebut dilakukan melalui siraman rohani di pengajian-pengajian atau pondok pesantren, bahwa turut berjuang membela negara merupakan bagian dari wujud keimanan umat muslim. Selain itu, para pemuda muslim setempat membentuk berbagai wadah perjuangan di tiap-tiap kampung dan lingkungan masjid, misalnya barisan pemuda Kauman yang anggotanya pernah aktif di badan-badan pendidikan militer Jepang seperti Keibodan, Seinendan, Heiho, Peta, dan Hizbullah. Mereka berjuang dengan berlandaskan ajaran Islam jihad fii sabilillah. Maka dari itu, mereka rela berkorban untuk menghilangkan kedhaliman para penjajah yang dianggap kafir.

Atas perlakuan pemuda-pemudi itu, pemerintah Jepang akhirnya mengambil tindakan dengan melucuti senjata kesatuan Polisi Istimewa di Gayam. Para pemuda tidak terima atas pelucutan tersebut, akhirnya mereka berhasil mendapatkan kembali senjatasenjata itu dari genggaman militer Jepang yang kemudian dibagi-bagi untuk modal perjuangan selanjutnya. Tidak puas, para pemuda memutuskan untuk melancarkan serangannya ke markas militer Jepang di Butai Kota Baru untuk menghilangkan pendudukan Jepang di Yogyakarta. Terjadilah pertempuran di antara para militan Jepang dengan kesatuan militer di Yogyakarta seperti BKR, Polisi Kota, Polisi Istimewa, serta Laskar Rakyat Bambu Runcing. Dalam pertempuran tersebut, tokoh-tokoh Islam Kauman banyak yang memegang posisi penting. Pertempuran ini mengakibatkan di pihak militer Yogyakarta gugur 21 orang dan 32 orang lainnya mengalami luka-luka. Para pejuang yang gugur dari Kauman seperti Moh. Tarom dan Abu Bakar Ali akhirnya dimakamkan di belakang Masjid Besar Kauman.

Akhirnya, kekuasaan Jepang di Indonesia diserahkan kepada Sekutu pada 29 September 1945. Angkatan perang Inggris yang diboncengi oleh pihak Belanda (Netherland Indies Civil Administration) tiba di tanah air dengan tujuan untuk menjajah kembali. Hal tersebut mengakibatkan kedudukan ibu kota yang semula berada di Jakarta lalu dipindahkan ke Yogyakarta karena dianggap dapat bertahan kuat dalam mempertahankan kemerdekaan Indonesia. Mendengar pemindahan ibu kota Indonesia, 
Belanda langsung menuju ke Yogyakarta untuk melakukan penyerangan terhadap wilayah tersebut.

Perlahan demi perlahan, para tentara Belanda mulai melancarkan agresinya yang pertama pada bulan Mei 1947. Hal tersebut dilakukannya dengan mengirimkan 100.000 serdadu bersenjata ke wilayah Jawa terutama Yogyakarta. Hal tersebut sontak mendorong para ulama-ulama untuk turut membantu kembali dalam mempertahankan kemerdekaan Indonesia dari jajahan Belanda. Akhirnya pada 23 Juli 1947, para ulama di Yogyakarta membentuk Markas Ulama Angkatan Perang Sabilillah yang berpusat di Masjid Besar Kauman. Lalu Ki Bagus Hadi Kusuma, K.H. Mahfud Siraj, dan K.H. Ahmad Badawi menyampaikan tekad tersebut kepada Sri Sultan Hamengku Buwono IX. Selanjutnya, tekad tersebut direspon baik oleh Sri Sultan dengan dikeluarkannya surat keputusan dan dihubungkan langsung dengan Panglima Besar Sudirman untuk melatih para anggota Angkatan Perang Sabil. Anggota dari Angkatan Perang Sabil ini sebagian besar merupakan pemuda-pemuda dari Kauman, antara lain Moh. Wardani, Djumidi, Moh. Djirhas, Moh. Daroni, Alip, Djumairi, Ardani, Syamsudin, Arsyam, Djaidun, H. Barozie, Hajid, Moh. Asief, Ahmad Dahlan, Djulban, Zuchri, Duchon, Djarid, Wildan, Djazuli, Musamma, Moh. Glompong, dan Suryadi (Setiawati, 1988).

Menurut saksi mata, para anggota Angkatan Perang Sabil biasa berlatih di pelataran Masjid Besar Kauman yang dipimpin oleh M. Sarbini. Setelah dilatih, mereka dikirim ke daerah Mranggen yang dipimpin oleh komandan K.H. Juraimi dengan dampingan K.H. Hadjid sebagai imam. Melihat situasi konflik fisik yang dilancarkan pasukan Belanda semakin memperparah pertahanan Indonesia, akhirnya mereka dikirim ke daerah Srondol untuk menahan serangan dari Belanda yang didampingi oleh empat imam yaitu Djauhari, K.H. Dahlan, K. Sahid, dan K. Bajuri yang tergabung dalam barisan Jenggot. Tugas mereka hanyalah memberikan semangat dan moral bagi para anggota bersenjata Angkatan Perang Sabil. Di samping itu, Angkatan Perang Sabil dalam perjuangannya bekerja sama dengan Angkatan Oemat Islam yang turut bermarkas di pelataran Masjid Besar Kauman. Atas perintah dari Panglima Besar Sudirman dan Sri Sultan Hamengku Buwono IX, para anggota Angkatan Perang Sabil dikirim ke Kebumen yang dipersenjatai dengan 120 pucuk senjata.

Di saat Belanda berhasil memasuki wilayah Yogyakarta, pada 27 Mei 1949 pasukan Belanda melakukan patroli di sepanjang jalan Ngabean menggunakan mobil jeep untuk mengejar para gerilyawan Angkatan Perang Sabil. Begitu sampai di rumah Abdul Gani, para pasukan Belanda pun turun ke lorong kampung Kauman dan bertemu dengan para anggota Angkatan Perang Sabil yang sedang berjaga di pos. Tanpa ragu-ragu, pasukan Belanda menembakinya secara membabi buta yang mengakibatkan gugurnya 3 anggota Angkatan Perang Sabil, antara lain H. Ilyas, H. Barozie, dan Zaidun. Selain itu, akibat penembakan tersebut jatuh korban pula 2 anak-anak yaitu Fu'ad dan Sudaryo serta 2 orang yang sedang sholat di Masjid Besar Kauman. Jenazah mereka disemayamkan di makam Syuhada' Barat Masjid Besar Kauman.

Warga Kauman yang turut serta dalam berjuang mempertahankan kemerdekaan tidak hanya tertuju pada kaum ulama yang mayoritas laki-laki saja, melainkan para perempuan pun turut serta dalam membantu menyediakan makanan dan obat-obatan. Dalam hal dapur umum, para pemudi dan ibu-ibu pengajian mengambil alih tugas tersebut. Perempuan-perempuan Kauman ini tergabung ke dalam organisasi yang 
bernama Aisyiyah. Selain Aisyiyah, organisasi Persatuan Wanita Indonesia pun turut membantu mengurus dapur umum selama masa revolusi tersebut terutama di Yogyakarta. Adapun dalam hal perawatan dan perobatan, Palang Merah Indonesia bekerja sama dengan para perempuan Aisyiyah dalam menangani para tentara yang terluka.

Setelah perundingan Roem-Royen, ibu kota Indonesia dikembalikan ke wilayah Jakarta. Lalu para anggota Angkatan Perang Sabil dikembalikan juga ke masyarakat, ada yang kembali pada profesi sebelumnya, ada pula yang meneruskan pendidikan belajarnya, serta ada yang bergabung pada kesatuan TNI.

\section{Batik Kauman}

Kampung Kauman merupakan salah satu destinasi yang pantas dikunjungi. Selain terkenal dengan ulamanya, juragan batik juga merupakan salah satu pekerjaan yang penting pada masanya. Batik dari Kampung Kauman bisa dibilang salah satu batik yang fenomenal, selain karena batik itu sendiri merupakan Warisan Budaya yang ditetapkan UNESCO, batik dari Kampung Kauman merupakan batik yang memiliki inspirasi dari Keraton itu sendiri.

Batik Kampung Kauman memiliki namanya sendiri yaitu Batik Sudagaran. Disebut sebagai Batik Sudagaran karena mayoritas masyarakat Kampung Kauman sendiri itu adalah kaum saudagar atau usahawan batik yang kaya dan keduanya memiliki hubungan dengan para ningrat di Keraton ("Sejarah Batik Yogyakarta”, 2017). Batik Keraton eksklusif hanya untuk para ningrat saja dan tidak boleh dikenakan oleh umum karena beberapa alasan tertentu, walaupun sebenarnya Batik Sudagaran ini banyak yang terinspirasi dari Keraton. Batik Sudagaran ini banyak meniru motif batik Keraton namun memodifikasikannya di beberapa aspek sehingga memiliki perbedaan dengan batik yang ada di Keraton. Seperti batik bermotif Parang yang hanya diperuntukkan untuk Raja, ditiru oleh pengrajin batik Kauman dengan cara mengecilkan motif Parang sehingga gambar Parangnya lebih kecil dari ukuran yang asli. Dengan demikian Keraton tidak akan bisa meng" claim" bahwa batik tersebut merupakan milik Keraton. Hal ini menunjukkan tingkat kreatifitas masyarakat yang sangat tinggi dan kepintaran masyarakat dalam mencari celah dalam suatu larangan. Maka dari itu, batik ini terkesan sangat berani karena menggunakan motif larangan kemudian diubah sehingga dapat digunakan oleh masyarakat umum ("Sejarah Motif Batik Sudagaran dan Penjelasannya", 2017). Hal ini merupakan bentuk usaha dari masyarakat untuk meniru sang Raja karena pada hakikatnya masyarakat memiliki kecenderungan meniru/mengikuti pemimpin atau "role model" mereka. Kerajinan batik ini sempat menjadi tren di kampung Kauman sehingga pengrajin batik pun tumbuh pesat di desa ini dan menjadi sumber penghasilan utama selain menjadi "Abdi Dalem".

Batik Saudagaran ini berawal dari keisengan para istri Abdi Dalem Keraton dalam mengisi waktu luang mereka yang kemudian menjadi suatu kerajinan yang dapat menghasilkan penghasilan tambahan dan bahkan menyaingi penghasilan suami mereka sendiri (Darban, 2000). Lebih tepatnya, batik Sudagaran ini lahir di tangan wanita anggota organisasi Aisyiyah atau organisasi Wanita Islam yang digagas oleh KH. Ahmad Dahlan (Hayati, 2009). Pada awalnya hasil dari keisengan para istri ini hanya ditampung dua orang yang dipercaya dapat menjualkannya ke khalayak luas, namun makin lama penjualan ini makin besar dan banyak yang mendirikan usaha dan menjual 
batiknya sendiri tanpa harus melalui perantara sehingga kerajinan yang tadinya hanya pekerjaan "sambilan" menjadi suatu kegiatan yang mengarah kepada pengusahaan yang memakai tenaga buruh yang mendapat upah kerja. Tahun 1910 muncul lah perusahanperusahaan batik Kauman atau yang lebih dikenal dengan Batik Handel. Pesanan batik berdatangan dari beberapa daerah nasional antara lain dari Jakarta, Medan, Semarang, dan Surabaya (Darban, 2000). Selain itu kemudahan dalam mendapatkan bahan-bahan pembuatan batik dengan status mereka sebagai Abdi Dalem, mendapat kepercayaan dari pemerintahan. Perkembangan batik pun juga tidak bisa lepas dari Muhammadiyah yang keduanya memiliki hubungan simbiosis mutualisme yang mengakibatkan keduanya sama-sama berkembang pesat.

Batik ini dijual di Kauman saja, kemudian banyak kosumen lokal bahkan mancanegara berkunjung ke Kampung Kauman untuk membeli batik sehingga batik tersebut. Walau demikian, penjual batik Kauman juga terkadang mengirim batik tersebut ke luar Kauman apabila ada pesanan dari luar daerah. Terkadang mengalami kesulitan dalam perjalanan dan sempat terjadi insiden pengusiran dari salah satu daerah yang didatangi karena tidak diizinkan berjualan di daerah tersebut. Persebaran motif pun juga tergantung dari pemesanan karena adanya usaha Kauman dalam penyesuain produksi batik dengan selera daerah pemesan. Pada tahun 1922 perkembangan dan kemajuan batik di Kauman mencapai puncaknya dan masa ini mendapat julukan Jaman Batik. Pada saat ini, dari 169 pengusaha batik yang ada di Jogja, 26 diantaranya berasal dari Kauman (Nurhadi, 2015). Namun seiring perjalanan waktu, banyak pengrajin yang gulung tikar karena pamor batik tulis menurun karena munculnya batik cap yang lebih praktis dan cepat serta munculnya koperasi batik yang mengakibatkan pengusaha mandiri banyak yang tutup dan kalah oleh para pembatik besar. Selain itu, pada tahun 1939 terjadi krisis ekonomi dunia yang menyebabkan ketidaksanggupan pemerintah dalam mengimpor bahan-bahan pembuatan batik sehingga terjadi kesukaran dalam memperoleh bahan-bahan membatik yang membuat beberapa pengusaha bangkrut (Darban, 2000). Bersaman dengan ini penjajahan bangsa Jepang makin memperparah kondisi ini, tetapi dari semua pembatik yang gulung tikar ada salah satu yang dapat dikatakan masih bertahan adalah batik Haji Bilal yang pada masanya merupakan juragan terkenal dan paling awal muncul. Haji Bilal juga merupakan salah satu juragan yang dititipkan oleh para pembatik pada zaman dahulu untuk menjual hasil kerajinan batik dari para pengrajin. Hal lain yang menyebabkan surutnya kejayaan batik di Kauman pada saat pasca kemerdekaan kerajinan batik adalah karena adanya campur tangan Cina terhadap pasar tekstil di Indonesia. Selain itu juga masalah kekurangan modal dan tak ada penerus pun juga menjadi alasan kenapa banyak pengusaha gulung tikar. Faktor lainnya adalah meningkatnya tingkat pendidikan masyarakat di Kauman yang membuat masyarakat Kauman beralih kepada profesi yang lebih profesional dan menjanjikan seperti pegawai, pendidik, dan sebagainya (Nurhadi, 2015). Batik ini dikatakan sudah tidak diproduksi lagi yang ditandai dengan akhir perusahaan batik cap pada tahun 1996, namun sebenarnya ada juga yang masih memproduksinya yaitu beberapa sesepuh yang masih melestarikan kegiatan membatik, walau mungkin sudah tidak dijual lagi. Beberapa pembatik yang masih bertahan salah satunya adalah Ibu Istinaro, istri dari cucu KH. Ahmad Dahlan, yang juga beliau menyimpan beberapa contoh dari batikbatik asli hasil buatan kampung Kauman pada zaman dahulu. 


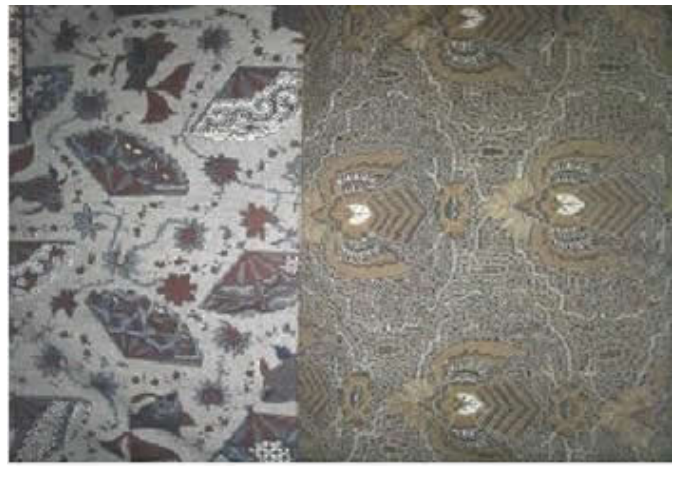

Foto 6. Batik Semen Sudagaran (Sumber: http://4.bp.blogspot.com/BoQhLjSqXME/URmzM_NodEI/ AAAAAAAAAD8/OnrQM6EI-_0/ s1600/sudagaran.jpg.)

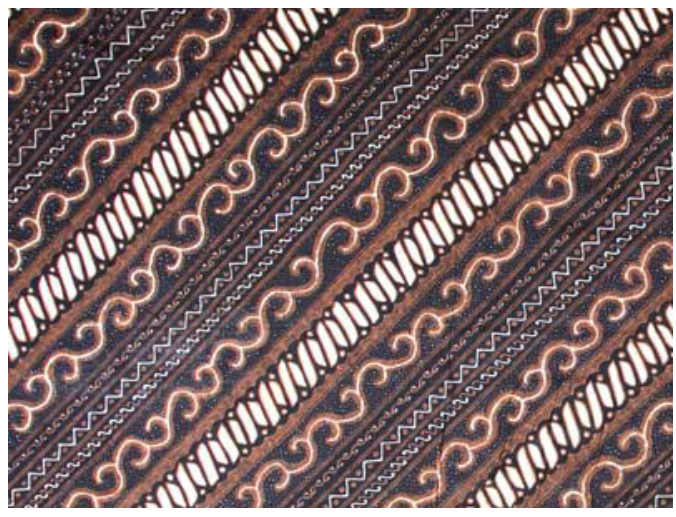

Foto 8. Batik Lereng Sudagaran (Sumber: http://2.bp.blogspot. com/-JoR6Iy320oA/UMt9uSw5xgI/ AAAAAAAAADM/M-EmclfBLpk/ s1600/barik+tulis+jogja.jpg)

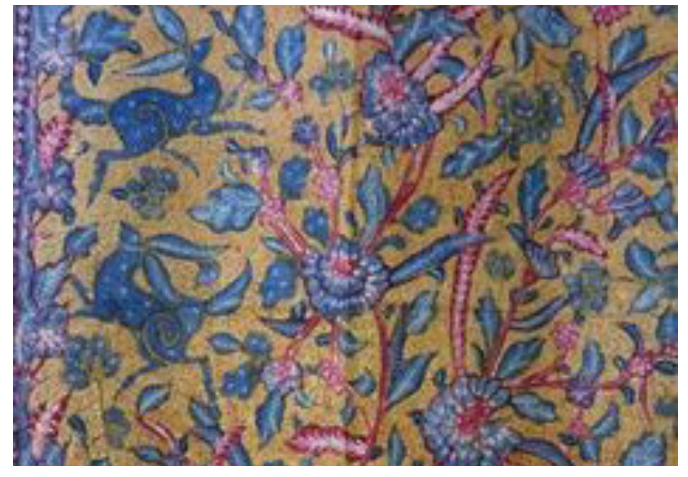

Foto 7. Batik Semen Sudagaran

(Sumber: https://i.pinimg. $\mathrm{com} / 236 \mathrm{x} / \mathrm{fe} / 01 / 85 /$ fe018593135890a5eed70e9065113f2f-batik-art.jpg)

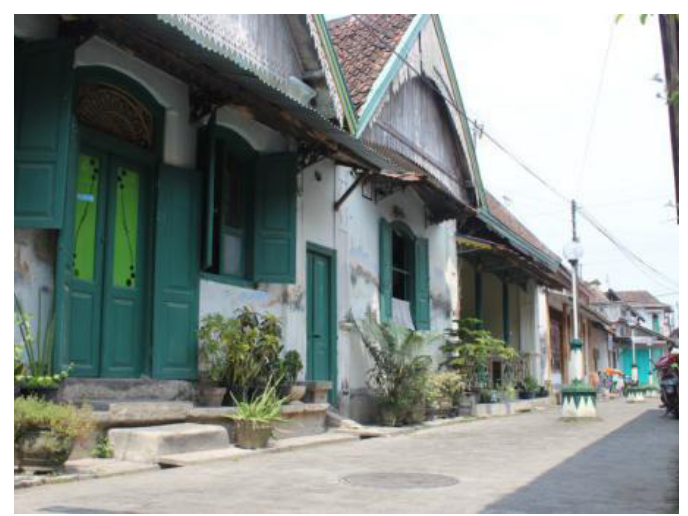

Foto 9. Rumah Juragan Batik (Sumber: https://dolandolen.com/ wp-content/uploads/2015/11/ Kampung-Kauman-Cover.jpg).

Motif batik Kauman ini bermacam-macam dengan pembuatan yang tekniknya juga tentu berbeda-beda, namun biasanya motif yang pakai adalah motif-motif klasik. Dua contohnya adalah motif Lereng dan Semen. Lereng merupakan motif batik nonobjek, tetapi hanya motif garis-garis membentuk kotak-kotak seperti keramik. Motif Semen yang berasal dari kata "semi" merupakan motif gambar yang utuh. Motif pada batik yang disebut Sudagaran ini bisa dilihat pada motif Parang yang hanya bentuk garis, kotak-kotak. Namun ada juga motif batik keraton yang dimodifikasi dari segi ukuran, antara lain motif gambar garuda yang digambar lebih kecil.

Pembuatan batik sangatlah didukung oleh pemerintah dan tokoh terpandang di Kampung Kauman tersebut yaitu KH. Ahmad Dahlan. Terutama KH. Ahmad Dahlan yang sangat terlihat mendukung, mulai dari upaya melibatkan batik dalam 
perkembangan Muhammadiyah, sampai pada usaha menjual batik dengan menjulanya sendiri pada saat mengadakan perjalanan bisnis ke seluruh Jawa bahkan sampai ke luar Jawa (Nurhadi, 2015). Kemudian selain KH. Ahmad Dahlan, para suami dari wanita pengrajin batik juga mendukung dengan cara membantu mereka mendapatkan bahan dari pemerintah serta membantu memproduksi batik tersebut dengan cara yang sudah pernah disebutkan diatas.

Sekarang di Kauman terdapat beberapa rumah-rumah Juragan Batik yang mayoritas berukuran besar dan terlihat "mewah". Rumahnya terlihat lebih memanjang dan memiliki arsitektur rumah Indis atau perpaduan antara gaya Eropa dengan gaya Jawa. Hal ini menunjukan bahwa usaha batik pada masanya membuat si pengusaha makmur dalam segi ekonomi sehingga dapat membangun rumah yang besar dan sekaligus menjadi tempat produksi batik. Sekarang rumah-rumah tersebut sudah beralih fungsi menjadi kost-kostan, asrama dan hal sejenis. Kemudian dengan kemakmuran dan kekayaan ini, banyak digunakan oleh pengusaha untuk membiayai pendidikan anak-anak mereka ke pendidikan yang tinggi dan bermutu, bahkan ada yang sampai disekolahkan di luar negeri. Salah satu contohnya adalah keluarga H. Moeh dan Ibu Ngaisa.

\section{Kuliner Kauman}

Makanan khas andalan Kauman biasanya berbentuk kudapan atau makanan ringan yang biasanya dijadikan snack kalau ada acara besar. Makanan khas Kauman ini sudah terkenal luas di Jogja, namun sering dilupakan asal-usulnya. Masyarakat Kauman merupakan masyarakat yang tinggal di dekat Masjid Gedhe Kauman, yang seringkali menjadi tempat Sultan mengadakan beberapa acara. Sebagai tuan rumah, ibu-ibu dari kampung Kauman ini sering membuat makanan lezat dan berkualitas untuk disuguhkah kepada Sultan saat ada acara di Masjid Gedhe Kauman. Selain itu melalui suguhan makanan tersebut, diharapkan Sultan akan mempercayakan kepada mereka dalam mengurus konsumsi pada saat acara-acara tertentu. Hal ini pun juga mendorong masyarakat untuk tidak hanya memproduksi satu atau dua jenis makanan saja, namun beragam makanan yang akan membuat Sultan tidak bosan dengan makanan dari kampung Kauman. Selain itu kemunculan dan ketenaran makanan khas Kauman disebabkan oleh munculnya keberadaan Pasar Tiban yang terjadi pada sekitar tahun 90-an. Uniknya kemunculan Pasar Tiban berawalkan dari sebuah warung kecil yang dimiliki oleh penduduk Kauman bernama Wono. Kemudian pemilik warung ini sangat suka berinovasi membuat makanan ringan sehingga berkembang lah kuliner di Kauman dan dari warung kecil tersebut, terbentuklah sebuah pasar bernama Pasar Tiban. Setiap bulan Ramadhan, Kampung Kauman selalu menggelar pasar sore kuliner yang terletak di Kampung Kauman itu sendiri. Pasar Kuliner Ramadhan di Kauman ini merupakan salah satu pasar sore pertama diadakan dibandingkan pasar kuliner lainnya. Pasar ini juga menjadi sebuah ikon tersendiri bagi Kampung Kauman dan menjadi pelopor munculnya pasar kuliner tahunan yang diadakan setiap bulan Ramadhan ("Pasar Sore Kuliner di Kampung Kauman”, 2012).

Masyarakat Jawa pada umumnya tidak bisa lepas dengan yang namanya santan pada saat memasak makanan. Santan sudah secara tidak langsung menjadi bahan ikonik masyarakat Jawa dalam memasak. Kuliner Kauman pun juga begitu, hampir semua makanan yang menjadi makanan khasnya menggunakan santan sebagai bahan 
utama, tidak heran jika kuliner Kauman disukai oleh banyak kalangan. Santan ini bisa diubah menjadi makanan yang gurih maupun yang manis oleh Kampung Kauman. Selain santen ada satu lagi yang biasanya sering digunakan dalam pembuata produk kuliner di Kauman, yaitu kelapa dalam bentuk parutan. Contoh makanan Kauman adalah Kicak, Semar Mendem, Kue Lumpur, Mentuk, Untuk-Untuk, Oblok-oblok, Matur Nungso, Megono, dan Perut Ayam.

Kicak adalah makanan yang dapat dibilang paling terkenal dan yang masih dikenal sebagai makanan khas Kauman. Kicak ini merupakan suatu makanan ringan yang mirip seperti jadah, namun perbedaannya dengan jadah adalah Kicak menggunakan nangka dan parutan kelapa sebagai bahan-bahan pembuatnya. Kicak ini tidak bisa dinikmati setiap saat, karena kicak biasanya diproduksi dan dijual saat bulan Ramadhan yang dijadikan santapan pembuka puasa. Semar mendem menggunakan ketan sebagai bahan utama dan telur. Bentuk dari makanan ini mirip dengan lemper, dibalut dengan telur dadar yang tipis bukannya dengan daun pisang. Makanan khas lainnya adalah Megono, yang pada awalnya Megono ini hanya dihidangkan untuk Keraton Raja saja. Namun seiring perjalanan waktu, Megono ini mulai menjadi makanan semua kalangan. Megono dibuat dari sayur-sayuran sebagai bahan utama yang dicampur dengan parutan kelapa. Sayuran yang disajikan dapat berupa sayuran matang maupun mentah dan seringkali menjadi makanan lalapan.

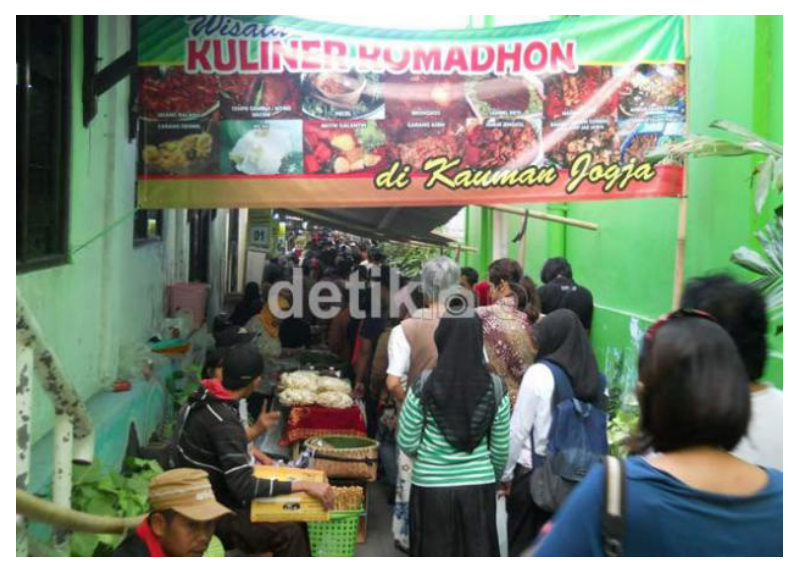

Foto 10. Pasar Kuliner Ramadhan (Sumber: https://news.detik.com/ foto-news/d-1972798/pasar-sore-kuliner-di-kampung-kauman/3\#)

\section{Kesimpulan dan Rekomendasi}

\section{Kesimpulan}

Kegiatan pengabdian kepada masyarakat yang dilaksanakan di Kampung Kauman oleh staf pengajar di Fakultas Ilmu Budaya dapat diterima oleh masyarakat kauman, khususnya para pengurus di Saka wisata. Kegiatan pengabdian kepada masyarakat antara lain dilaksanakan dalam bentuk pendampingan dan pelatihan dalam mengumpulkan sumber sejarah kampung Kauman yang dipandu oleh sejarawan dari Fakultas Ilmu Budaya. Hasil output kegiatan yang berupa cerita-cerita sejarah yang dihasilkan dalam kegiatan pengabdian kepada masyarakat dapat disajikan kepada para wisatawan yang 
mengunjungi kampung wisata Kauman, sehingga wisatawan betul-betul mengetahui sejarah Kampung Kauman.

\section{Rekomendasi}

Kegiatan pengabdian kepada masyarakat di Kampung Kauman ini dapat dilanjutkan lagi di masa depan dengan materi yang dapat mendukung peningkatan kampung Kauman sebagai Kampung wisata yang berbasis komunitas dan yang sesuai dengan potensi yang dimilikinya. Dengan demikian, diharapkan potensi kuliner, pengembangan batik, dan peninggalan sejarah Kampung Kauman dapat dinikmati dan dipahami oleh wisatawan secara menyeluruh. Kegiatan pengabdian kepada masyarakat semacam ini direkomendasikan untuk dapat dilangsungkan di Kampung lain yang memiliki potensi kampung wisata.

\section{Daftar Pustaka}

\section{Buku dan Jurnal:}

Ahmad Sarwono bin Zahid dan Shofrotum binti Husein Al-Aydrus. (2013). K.H.R.Ng. Ahmad Dahlan: Pembaharu, Pemersatu, dan Pemelihara Tradisi Islam. YogyakartaL Mitra Aksara Mulia.

Alfian, Ibrahim. (1987). Perang di Jalan Allah. Jakarta: Pustaka Sinar Harapan.

Atmojo, Junus Satrio. (1989/1999). Masjid Kuno Indonesia, Proyek Pembinaan Peninggalan Sejarah dan Kepurbakalaan Pusat.

Basundoro, Purnawan. (2016). Pengantar Sejarah Kota. Yogyakarta: Ombak.

Darban, Ahmad Adaby. (1994). Sejarah Muhammadiyah Bagian I. Yogyakarta: Pimpinan Pusat Muhammadiyah Majelis Pustaka.

Darban, Ahmad Adaby. (2000). Sejarah Kauman: Menguak Identitas Kampung Muhammadiyah. Yogyakarta: Tarawang.

Darban, Ahmad Adaby (2005). Kaum Santri Melawan Kolonial: Dari Hizbullah hingga Angkatan Perang Sabil (APS) di Yogyakarta. Bandung: Forum Diskusi dan Pameran 60 Tahun Indonesia Mereka dalam Dalam Lintasan Sejarah.

Jandra, Mifedwil. (1989-1990). Perangkat/Alat-alat dan Pakaian Serta Makna Simbolis Upacara Keagamaan di Lingkumgan Keraton Yogyakarta, Departemen Pendidikan dan Kebudayaan.

Maarif, Syafii. (1986). Islam dan Masalah Kenegaraan, Jakarta: LP3ES.

Manshur, Fadlil Munawwar. (1998). Budaya Pesantren dan Tradisi Pengajian Kitab, dalam Jurnal Humaniora No. 8 tahun 1998.

Manshur, Fadlil Munawwar. (1993). Suara Aisyiyah Volume 68. Yogyakarta: Yayasan Penerbit Pers Aisyiyah.

Manshur, Fadlil Munawwar. (1995). Buku Kenangan 50 Tahun Reublik Indonesia di Yogyakarta, Sebuah Lintasan Sejarah. Yogyakarta: Panitia Gabungan Peringatan HUT RI ke-50 Kemerdekaan RI Bhakti Pertiwi Prop. DIY.

Moedjanto. (1994). Kasultanan Yogyakarta dan Kadipaten Pakualaman. Yogyakarta: Kanisius.

Ricklefs, M.C. (2008). Sejarah Indonesia Modern 1200-2008. Jakarta: PT. Serambi Ilmu Semesta. 
Sairin, Weinata. (1995). Gerakan Pembaruan Muhammadiyah, Jakarta: Pustaka Sinar Harapan.

Setiawati, Nur Aini. (1988). "Askar Perang Sabil: Studi Sosio-Religius Dalam Perjuangan Kemerdekaan Republik Indonesia Di Daerah Istimewa Yogyakarta 1945-1949”, Skripsi FIB, UGM)

Soemohadiwidjojo, Rhien (2013). Bung Karno Sang Singa Podium. Second Hope.

Surjomihardjo, Abdurrachman. (2000). Kota Yogyakarta: Sejarah Perkembangan Sosial, Yogyakarta: Yayasan Untuk Indonesia.

Sutrisno Kutoyo, (1996). Sri Sultan Hamengku Buwono IX: Riwayat Hidup dan Perjuangan. Jakarta: Mutiara Sumber Widya.

Tashadi, dkk (1991). Sejarah Revolusi Kemerdekaan (1945-1949) di Daerah Istimewa Yogyakarta. Jakarta: Proyek Inventarisasi dan Dokumentasi Sejarah Nasional.

Tashadi, dkk, (2000). Keterlibatan Ulama di DIY pada Masa Perang Kemerdekaan Periode 1945-1949. Jakarta: Depdiknas.

\section{Wawancara:}

Wawancara dengan Pak Gatot, salah satu pengurus Saka Wisata Masjid Kauman pada Jumat, 10 November 2017.

Wawancara dengan Mbah Junadah selaku anggota Nasyiatul Aisyiyah pada saat revolusi, pada Sabtu, 6 Mei 2017.

Wawancara dengan Bapak Ibu Istinaroh

Wawancara dengan Ibu Hadhiroh,

Ibu Kusniah, Bapak Abunda Farouk, Bapak Budi Seiawan

\section{Sumber Elektronik:}

Hayati, Latifa. (2009). Peran Aisyiyah dalam Internalisasi Nilai-Nilai Muhammadiiyah di Kampung Kauman Yogyakarta. Diambil dari http://digilib.uin-suka.ac.id/2930/ dan diakses tanggal 11 November 2017.

Kurniawan, Bagus. (2012). Pasar Sore Kuliner di Kampung Kauman. Diambil dari https://m.detik.com/news/foto-news/d-1972798/pasar-sore-kuliner-di-kampungkauman/5\#detailfoto dan diakses tanggal 11 November 2017.

Nurhadi, N. (2015). Bab III Dinamika Perubahan Sosial Ekonomi Masyarakat Kauman Yogyakarta Tahun 1916-19990. Diambil dari http://digilib.uinsby.ac.id/3863/6/ Bab\%203.pdf dan diakses tanggal 11 November 2017.

Sejarah Batik Yogyakarta. Diambil dari http://jogjaworldbatikcity.id/sejarah-batikyogyakarta/ dan diakses tanggal 10 November 2017.

Sejarah Motif Batik Sudagaran dan Penjelasannya. Diambil dari http://batik-tulis.com/ blog/batik-sudagaran/ dan diakses tanggal 11 November 2017. 